13. Статут Міжнародного Суду OOH. URL: https://zakon.rada.gov. ua/laws/show/995_010).

14. Топорнин Б.Н. Европейское право : учебник. Москва, 2001.

15. Трстеньяк В. Принцип верховенства в праве Европейского союза и роль конституционных судов государств-членов. Международное правосудие. 2012. № 2. URL: http://center-bereg.ru/ o1361.html

16. Хартія основних прав Європейського Союзу : [пер. А. Пендак]. Ніцицький договір та розширення Європейського Союзу. Київ, 2001. 124 с.

17. Case 26/62, NV Algemene Transport- en Expeditie Onderneming van Gend \& Loos v Netherlands Inland Revenue Administration II European Court Reports. 1963.

18. Case 294/83, Parti ecologiste «Les Verts» v European Parliament II European Court Reports. 1986. P. 1339.

19. Case 6/64, Flamino Costa v. E.N.E.L. II European Court Reports. 1964. P. 585.

20. Opinion 1/76, Draft Agreement establishing a European laying-up fund for inland waterway vessels II European Court Reports. 1977. P. 741.

УДК 341.4

DOI https://doi.org/10.32844/2618-1258.2019.3-2.42

ЛАКІЙЧУК Я.О.

\title{
МІЖНАРОДНИЙ ДОСВІД ЗДІЙСНЕННЯ ПРЕВЕНТИВНИХ ЗАХОДІВ ОРГАНАМИ ПОЛІЦЇ̈ ТА МОЖЛИВОСТІ ЙОГО ВИКОРИСТАННЯ В УКРАЇНІ
}

У статті на основі аналізу наукової літератури досліджено досвід провідних країн Європи щодо здійснення превентивних заходів органами поліції та визначено можливості його використання в Україні. 3'ясовано, що в одних країнах робиться акцент на розширення повноважень поліцейських, в інших - на максимальну взаємодію із громадянами, залучення їх для допомоги у реалізації окремих поліцейських функцій, а в третіх - узагалі ще не вироблено ані поняття, ані сутності превенції як форми діяльності поліції. У зв'язку із цим не можна взяти за основу досвід якоїсь одної країни для імплементації в межах національних реалій.

Звернуто увагу на такий приклад взаємодії поліції та населення Великобританії щодо забезпечення публічного порядку та підвищення рівня безпеки громадян у районах їх проживання, як програма «Сусідське спостереження», основним призначенням якої постає спостереження за підозрілими людьми або потенційно небезпечними подіями, що відбуваються в районі проживання.

3'ясовано, що у Великобританії поряд із поліцією правоохоронного-превентивні функції здійснюють: по-перше, органи для яких функція охорони публічного порядку є другорядною (такі органи не є поліцейськими у власному значенні цього слова та складаються із цивільних службовців); по-друге, громадяни, що мають законодавчо встановлені повноваження у сфері охорони публічного порядку, зокрема, їм надано право припиняти злочини, а також доставляти правопорушників в органи поліції чи суду.

Зроблено висновок, що логічним є запозичення зарубіжного досвіду здійснення превентивних заходів у такому ракурсі: поглиблення «превентивних можливостей» поліцейських, розширення їхніх прав у сфері застосування превентивних заходів і полегшення механізму використання останніх; удосконалення нормативно-правової бази в частині детального регулювання процедур і порядку використання превентивних заходів, а також приведення іії у відповідність до міжнародних стандар-

(C) ЛАКІЙЧУК Я.О. - здобувач кафедри поліцейського права (Національна академія внутрішніх справ) 
тів у сфері здійснення превентивної діяльності; посилення взаємодії із населенням у процесі провадження превентивної діяльності; розроблення та упровадження різних поліцейсько-соціальних програм, спрямованих на профілактику правопорушень, проведення роз'яснювальної роботи серед різних верств населення, підвищення правосвідомості серед людей, роботи із особами, які входять у «групу ризику», тощо.

Ключові слова: зарубіжний досвід, превентивні заходи, органи поліиії, законодавство, правоохоронні органи.

In the article, based on the analysis of scientific literature, the experience of the leading European countries on the implementation of preventive measures by the police authorities is investigated and the possibilities of its use in Ukraine are determined. It was found that in some countries the emphasis is placed on expanding police powers, in others - maximizing interaction with citizens, involving them to assist in the implementation of certain police functions, while in the third countries neither concepts nor the essence of prevention as forms have been elaborated yet activities of the police. In this regard, one country's experience in implementing national realities cannot be taken as its basis.

Attention is drawn to the example of synergies between the police and the UK population in order to ensure public order and enhance the security of citizens in their areas of residence, such as the Neighborhood Surveillance Program, the primary purpose of which is to monitor suspected people or potentially dangerous developments in the area.

In the United Kingdom, it has been found that, in addition to law enforcement, preventive functions are performed by: firstly, bodies for which the public order function is of secondary importance (such bodies are not police officers in their own sense and are composed of civil servants); secondly, citizens who have statutory powers in the field of public order, in particular, are given the right to suspend crimes and to bring offenders to the police or court.

It is concluded that it is logical to borrow foreign experience of implementing preventive measures in such a perspective: deepening the "preventive capabilities" of police officers, expanding their rights in the field of preventive measures and facilitating the mechanism of their use; improving the regulatory framework in terms of detailed regulation of procedures and procedures for the use of preventive measures, as well as bringing it in line with international standards in the field of preventive activities; strengthening of interaction with the population in the process of carrying out preventive activity; development and implementation of various police and social programs aimed at the prevention of offenses, providing outreach to various segments of the population, raising awareness among people, working with persons at risk, etc.

Key words: foreign experience, preventive measures, police, legislation, law enforcement.

Вступ. Сьогодні і на законодавчому, і на науковому рівнях неодноразово акцентувалась увага на тому, що превентивні заходи, які здійснюються поліцією, $є$ недосконалими та потребують комплексного вдосконалення. В точних науках перевірка достовірності відкритої інновації забезпечується за допомогою проведення експерименту, який у праві неможливий у чистому вигляді, через те що в межах юриспруденції досліджуються не фізичні або математичні явища, що, відповідно, мають цифрове або фізичне, реальне, вираження, а закономірності змін суспільних відносин, підданих дії права на них. Однак чудовою заміною експерименту в правовій галузі $\epsilon$ проведення компаративістського аналізу, тобто розгляду та порівняння зарубіжного досвіду із національним, запозичення найкращих іноземних практик.

Аналіз останніх досліджень і публікацій. Окремі проблемні питання щодо превенції в діяльності правоохоронних органів у своїх наукових дослідженнях розглядали такі вчені: І.Я. Терлюк, О.Г. Бажан, Р.Ю. Подкур, С.К. Бостан, Г.Я. Дутка, М.В. Стащак, В.В. Шендрик, Г.Р. Парханов, К.О. Пісоцька, Д.О. Штанько, Т.А. Денисова, О.О. Книженко, В.Л. Кураков, А.Л. Кураков та багато інших. Варто зазначити, що вказані науковці зробили чималий внесок у розвиток вказано- 
го проблемного питання, однак досить багато його аспектів ще й досі $є$ невирішеними. Зокрема, особливої уваги заслуговує досвід країн, що досягли певних успіхів у цій сфері, та використання якого допоможе значно вдосконалити цей інститут в Україні.

Постановка завдання. Метою статті є дослідження міжнародного досвіду здійснення превентивних заходів органами поліції та визначення можливостей його використання в Україні.

Результати дослідження. Корисні, на нашу думку, до запозичення особливості превентивної діяльності правоохоронних органів $\epsilon$ на євразійському континенті, зокрема в багатьох європейських країнах. Візьмімо до прикладу досвід Великобританії в досліджуваній сфері. Необхідно зазначити, що реалізація правоохоронними органами своїх функцій забезпечується на нормативно-правовому рівні положеннями численних законодавчих актів, а саме - законами «Про поліцію» від 1964 року, «Про поліцію Шотландії» від 1967 року, «Про поліцію та кримінально-правове доказування» від 1984 року, «Про кримінальне судочинство та публічну безпеку» тощо [1].

Структурно поліція Великобританії складається із Міністерства внутрішніх справ - головного координаційного органу в правоохоронній сфері, а також поліцейських департаментів графств, транспортної поліції, поліції Північної Ірландії тощо. Характерною особливістю британської поліцейської системи є також те, що всі працівники британської поліції (від констебля і вище) наділені відповідними правами в частині досудового розслідування кримінальних справ. Окремого органу чи посадової особи, спеціально призначених для виконання цієї функції, у британській поліції немає. Окремо слід сказати про поліцейські функції коронерів - чиновників, які поєднують суддівські та слідчі функції. Коронери мають право застосовувати заходи процесуального примусу без санкції суду, тобто в адміністративному порядку та на свій розсуд, що $\epsilon$ специфічною формою англійської превенції [2, с. 462].

Важливо зауважити, що здійснення поліцією Великобританії превентивних заходів та їхня загальна ефективність великою мірою залежать від низки організаційних особливостей. Територія цієї країни розбита на поліцейські зони, за якими будується управління місцевими поліцейськими загонами. Отже, співробітники територіальних поліцейських сил мають повний обсяг повноважень лише в межах свого регіону, в межах інших - повноваження обмежені (за деякими винятками). Окрім того, у Великобританії поряд із поліцією правоохоронно-превентивні функції здійснюють: по-перше, органи для яких функція охорони публічного порядку є другорядною (такі органи не $є$ поліцейськими у власному значенні цього слова та складаються із цивільних службовців); по-друге, громадяни, що мають законодавчо встановлені повноваження у сфері охорони публічного порядку, зокрема, їм надано право припиняти злочини, а також доставляти правопорушників в органи поліції чи суду [3, с. 124].

Значного розвитку у Великобританії отримав сектор взаємодії поліції та населення, в результаті чого було розроблено та впроваджено велику кількість специфічних операційних стратегій, а саме: консультативні групи, піше патрулювання, контактне патрулювання, публічні констеблі, маркування власності тощо. Окремо необхідне звернути увагу на такий приклад взаємодії поліції та населення Великобританії щодо забезпечення публічного порядку та підвищення рівня безпеки громадян у районах їх проживання, як програма «Сусідське спостереження», основним призначенням якої постає спостереження за підозрілими людьми або потенційно небезпечними подіями, що відбуваються в районі проживання. Ця програма, фінансування якої здійснюється за кошти місцевих органів влади, у Великобританії має такі елементи: рекомендації поліції громадянам щодо забезпечення власної безпеки, безпеки сусідів, підвищення безпеки житла, зокрема щодо використання замків та інших технічних засобів, маркування майна, захисту від пожежі; підготовка анкет і проведення опитування мешканців щодо виявлення слабких ланок у системі заходів майнової безпеки (листи опитування містять пункти про правила поведінки та дотримання безпеки житла); участь публічності в роботі комісій щодо запобігання злочинності; пропаганда заходів програми [3, с. 124].

Розвиненою в плані організації, використання та забезпечення превентивної діяльності та передбачених нею превентивних заходів $є$ Німеччина. Систему поліцейських органів Німеччини складають:

- Федеральне міністерство внутрішніх справ Німеччини, яке несе відповідальність за забезпечення внутрішньої безпеки і захисту конституційного ладу, захист цивільного населення від лих і тероризму, адміністративні питання і спорт;

- Федеральна поліція - підпорядковується Міністерству внутрішніх справ безпосередньо та виконує комплексні завдання відповідно до Федерального закону про поліцію і низки інших законодавчих актів. 
Зазначити треба те, що Федеральна поліція тісно взаємодіє з організованою мережею різного роду служб безпеки федерального і земельного підпорядкування і на основі партнерства 3 колегами-поліцейськими федеральних земель і прикордонними службами зарубіжних країн. Поряд із цим $є$ також органи місцевої поліції. Наприклад, територія Німеччина складається із 16 федеральних земель, що мають власні поліцейські формування, організація яких у кожній землі своя. Це зумовлено тим, що згідно з Конституцією Німеччини формування і керівництво поліцейськими структурами $є$ власною прерогативою урядів федеральних земель [4, с. 6].

Децентралізований характер поліції також впливає на застосування цим органом превентивних заходів. Загалом, превентивна робота $є$ прерогативою місцевою поліції. Крім того, така діяльність суцільно «заточена» на максимальне залучення громадськості. Пов'язано це 3 тим, що Німеччина $є$ однією з найбільш досвідчених європейських країн, де суспільна орієнтація поліцейської діяльності дійсно працює, а не тільки «існує» в нормах писаних юридичних актів. В основу організації поліцейської діяльності Німеччини покладено таке: профілактика злочинності є спільним завданням держави і суспільства; нові стратегії безпеки спрямовані на суспільно-орієнтовану поліцейську роботу; громадяни залучаються як партнери поліції; профілактика злочинності є основоположним предметом кримінальної політики [5].

До того ж кожна з федеральних земель Німеччини приймає свої програми в межах загальної політики в сфері профілактики та запобігання злочинності, наприклад: утворюються спільні робочі групи служби зайнятості і поліції; реалізується політика в сфері боротьби з наркотиками (замісна терапія наркоманії); проводиться кампанія «Насильство - побачити - допомогти»; проводяться соціальні тренінг-курси «Антинасильство»; здійснюється суспільна допомоги постраждалим від насильства і таке інше [5].

Значні досягнення має німецька поліція у напрямі ювенальної превенції. Напрацювання в цій сфері характеризуються високим ступенем ефективності застосовуваних заходів. В основу стратегії профілактики правопорушень неповнолітніх у Німеччині покладено позицію, що схильність дитини до правопорушень $\epsilon$ тимчасовим проявом, а репресивні заходи лише негативно впливають на становлення особистості. Проте, зважаючи на розвиненість німецької системи правоохоронних органів із питань розслідування злочинів неповнолітніх, варто зазначити, що каральний підхід також $є$ значущим, однак основний акцент усе ж здійснюється на пошук причин і профілактику правопорушень серед дітей, що є характерними ознаками ресоціалізаційного підходу. Наприклад, досить високий рівень здійснення профілактики дитячої злочинності досягнутий у Західному Берліні. Для роботи з неповнолітнім у складі управління поліції створений спеціальний комісаріат, який здійснює реагування на всі доноси та інформацію щодо дітей [6, с. 185-187].

Досить важливе місце превентивні заходи посідають у діяльності поліції Польщі та Чехії. В цих країнах поліція володіє широким колом повноважень щодо здійснення превентивної роботи. У Чехії та Польщі є муніципальна (громадська) поліція, яка підпорядковується відповідному органу місцевого самоуправління і діяльність якої спрямована на профілактику правопорушень у сфері дорожнього руху і забезпечення громадського порядку в окремих муніципалітетах. Зокрема, до повноважень інспекторів муніципальної поліції належать: сприяння в забезпеченні безпеки осіб і власності в межах своїх повноважень; нагляд за дотриманням встановлених органами місцевого самоврядування правил поведінки в громадських місцях; нагляд за дотриманням правил дорожнього руху і громадського порядку; участь у запобігання правопорушень на конкретній території муніципалітетів; нагляд за дотриманням чистоти в громадських місцях [7].

Абстрагуючись суто від європейського досвіду, зазначимо, що багато цікавих і дієвих тенденцій здійснення превентивних заходів присутні в роботі органів поліції азіатських держав. Згадати в цьому контексті треба Японію, яка характеризується не тільки бурхливим технологічним прогресом але й значними надбаннями в сфері запобігання та профілактики правопорушень, використання громадськості у вирішенні завдань, що ставляться перед поліцією. Наголосимо, що в Японії, порівняно з іншими країнами, рівень злочинності (вбивство, крадіжка) досить низький. Це пов'язано, перш за все, із належним рівнем організації взаємодії населення й поліції. Відбувається це так: на кожній поліцейській дільниці функціонують відділення Асоціації запобігання злочинності, членом якої можуть стати не тільки пересічні громадяни, які бажають співпрацювати з органами правопорядку, але й об'єднання осіб за професіями, представники котрих частіше за інших стають жертвами злочинних посягань (водії громадського транспорту, працівники банківської сфери, торговельних мереж, листоноші та інші). Обов'язками членів асоціації є повідомлення працівників поліції про скоєні злочини та цілодобове патрулювання вулиць. Також на 
вулицях міст засновані так звані «інформаційні пункти». До добровольців цих пунктів можуть звернутися не тільки будь-який громадянин і отримати необхідну консультацію чи дієву допомогу, але і працівники поліції для отримання інформації про місцевих жителів, скоєння злочину чи розшук зниклої особи $[8 ; 9 ; 10$, с. 118].

Окрему увагу необхідно звернути на досвід країн пострадянського простору, до числа яких також належить Україна. Подібні держави мають схожі правові системи, через що імплементувати ïx досвід набагато простіше. Наприклад, у Грузії перелік превентивних заходів та їх нормативно-правове регулювання $є$ практично ідентичним до національної моделі, за винятком визначення окремих заходів, які в діяльності української поліції не використовуються взагалі або мають дещо інше правове обрамлення. Головною правовою основою поліції Грузії є Закон Грузії «Про поліцію». Відповідно до його положень поліція в цій державі - це система правоохоронних установ, якими здійснюється виконавча влада та які входять в систему Міністерства, яка в межах повноважень, наданих законодавством Грузії, проводить превентивні заходи і заходи з реагування на правопорушення для дотримання громадської безпеки та правопорядку [11]. Поліція з метою запобігання загрозі суспільній безпеці і правопорядку або припинення їх порушення застосовує в межах своєї компетенції такі превентивні заходи: опитування особи; ідентифікацію особи - зняття відбитків пальців і долонь, зйомка фотознімка, фіксування характерних фізичних ознак, вимірювання зросту, запис голосу, фіксування інших біометричних даних; запрошення особи - поліція має право для бесіди запросити особу в орган поліції шляхом повідомлення за наявності достатніх підстав вважати, що особа володіє необхідною для поліції інформацією, яка допоможе їй у виконанні своїх функцій, або для необхідності здійснення заходів щодо ідентифікації іншої особи; поверхневу перевірку і огляд; спеціальну перевірку і огляд; спеціальний поліцейський контроль - спеціальна перевірка і огляд як превентивний захід передбачає перевірку і огляд особи, речі або транспортного засобу на території чи об'єкті, підпорядкованому спеціальним режимом, необхідні для виявлення речі, а також для встановлення природи речі; вимогу покинути місце і заборону на вхід на конкретну територію; обмеження пересування особи або транспортного засобу або фактичного володіння річчю; застосування автоматичної фототехніки (радара) і відеотехніки; створення і використання технічних засобів; здійснення оперативно-розшукових заходів [11].

Висновки. Тож, розглянувши досвід багатьох країн, можна побачити, що є безліч підходів до процесу здійснення превентивних заходів органами поліції та провадження превентивної діяльності загалом. В одних країнах робиться акцент на розширення повноважень поліцейських повноважень, в інших - на максимальну взаємодію із громадянами, залучення їх для допомоги у реалізації окремих поліцейських функцій, а в третіх - узагалі ще не вироблено ані поняття, ані сутності превенції як форми діяльності поліції. У зв'язку із цим не можна взяти за основу досвід якоїсь одної країни для імплементації в межах національних реалій. Утім, якщо підійти до вказаної проблематики комплексно, то найбільш логічним є запозичення зарубіжного досвіду здійснення превентивних заходів у такому ракурсі:

- поглиблення «превентивних можливостей» поліцейських, розширення їхніх прав у сфері застосування превентивних заходів і полегшення механізму використання останніх;

- удосконалення нормативно-правової бази в частині детального регулювання процедур і порядку використання превентивних заходів, а також приведення її у відповідність до міжнародних стандартів у сфері здійснення превентивної діяльності;

- посилення взаємодії із населенням у процесі провадження превентивної діяльності;

- розроблення та упровадження різних поліцейсько-соціальних програм, спрямованих на профілактику правопорушень, проведення роз'яснювальної роботи серед різних верств населення, підвищення правосвідомості серед людей, роботи із особами, які входять у «групу ризику» тощо.

Це далеко не повний перелік тих аспектів зарубіжного досвіду, які можливо запозичити та використати. Але саме вони здатні змінити наявний формат роботи Національної поліції, піднявши превенцію як форму їі діяльності на новий, домінуючий рівень.

\section{Список використаних джерел:}

1. Бирюков П.Н. Полиция Великобритании. Авторская рубрика профессора Бирюкова П.Н. URL: https://eurasialaw.ru/nashi-rubriki/politsiya-gosudarstv-mira/politsiyavelikobritanii\#\#biryukov-p-n-d-yu-n-professor-zaveduyushchij-kafedroj-voronezhskogo-gu.

2. Соболь Є.Ю., Коломойцев С.С. Досвід організації та діяльності поліції провідних країн Європи. Форум права. 2010. № 2. С. 461-466. 
3. Комісаров С.А. Взаємодія поліції й населення як стратегічний напрям діяльності органів правопорядку: міжнародний аспект. Юридичний науковий електронний журнал. 2018. № 2. C. $123-126$.

4. Раевский П.А., Пархоменко С.А. Организация правоохранительной системы в некоторых федеральных странах мира. Комитет гражданской инициативы фонд «Индем». URL: http://www.indem.ru/proj/rpf/orpraohrsifederstra.pdf.

5. Случевская Ю. Зарубежный опыт партнерских отношений полиции и гражданина. Объединенная редакиия МВД России. 2012. URL: http://www.ormvd.ru/pubs/102/15425.

6. Бакаев А.А. Система профилактики правонарушений несовершеннолетних. Москва : Логос, 2004. 218 c.

7. Будь О. Организация и правовое регулирование применения превентивных полицейских мер в сфере обеспечения правопорядка в стране: опыт ряда стран Европы для Украины. Legea si viata: Закон и Жизнь: междунар. науч.-практ. журнал. 2019. № 2/2 (Februarie). C. 36-41.

8. Музичук О.М. Зарубіжний досвід участі громадян та громадських формувань в охороні громадського порядку і боротьбі з правопорушеннями. Право $і$ безпека : наук. журнал. 2002. Вип. 2. С. 101-105.

9. Бандурка О.М. Партнерські взаємовідносини між населенням та міліцією : підручник. Харків : Вид-во Нац. ун-ту внутр. справ, 2003. 352 с.

10. Бобро Н.В. Зарубіжні практики взаємодії поліції та населення. Сборник публикаиий мультидисциплинарного научного журнала «Архиваруис» по материалам V Международной научно-практической конференции: «Наука в современном мире» г. Киева: сборник со статьями (уровень стандарта, академический уровень). Киев : Мультидисциплинарный научный журнал «Архиваруис», 2016. С. 117-119.

11. О полиции : Закон от 28 октября 2013 г. № 1444-Ils. Законодательный вестник Грузии. URL: https://matsne.gov.ge/ru/document/view/2047533? publication=22.

УДК $341.1 / 8$

DOI https://doi.org/10.32844/2618-1258.2019.3-2.43

ПАЙДА Ю.Ю.

\section{ІМПЛЕМЕНТАЦІЯ ЗАРУБІЖНОГО ДОСВІДУ \\ НОРМАТИВНОГО ЗАБЕЗПЕЧЕННЯ ПРАВ ЛЮДИНИ ТА РЕЛІГІЙНОЇ СВОБОДИ ДО ВІТЧИЗНЯНОЇ ПРАВОВОЇ СИСТЕМИ}

Для побудови в Україні сучасної моделі відносин між державою і церквою доцільним є використання позитивних досягнень країн Західної Європи та колишнього «соцтабору», які значно випереджають нашу державу у сфері реалізації принципу релігійної свободи. Подібні «запозичення» сприятимуть максимальному наближенню української правової системи до світових і європейських стандартів, нададуть імпульс подальшій демократизації законотворчого процесу в цілому. У свою чергу, будуть створені передумови для забезпечення реалізації фундаментальних конституційно-правових норм, що гарантують дотримання демократичних прав і свобод людини, зокрема і релігійної свободи. Таким чином, практичні кроки нашої держави в напрямку імплементації кращих зразків зарубіжного досвіду нормативного забезпечення прав людини і релігійної свободи мають спрямовуватися на відповідність вітчизняного законодавства стандартам, визначеним у міжнародних нормативно-правових актах, до яких приєдналася Україна, створення належних умов задля ефективної роботи інститутів демократії, вільного обміну ідеями та інформацією тощо. Наголошено, що рішення Європейського Суду з прав людини, що стало

( ) ПАЙДА Ю.Ю. - кандидат юридичних наук, доцент, професор кафедри теорії та філософії права (Кам'янець-Подільський податковий інститут) 